УДК 159.942

DOI:

Борис Савчук, доктор історичних наук, професор кафедри педагогіки та освітніх технологій імені Богдана Ступарика ДВНЗ “Прикарпатський наиіональний університет"

Віра Ковальчук, кандидат педагогічних наук, дочент кафедри педагогіки та освітніх технологій імені Богдана Ступарика ДВНЗ “Прикарпатський національний університет імені Василя Стефаника"

\title{
ФОРМУВАННЯ ЕМОЦЙНОГО ІНТЕЛЕКТУ ЯК КОМПЕТЕНТНОСТІ МАЙБУТНЬОГО ФАХІВЦЯ: ПОСТАНОВКА ПРОБЛЕМИ
}

Здійснено спробу актуалізувати в освітньому і науково-педагогічному просторі України проблему формування емоційного інтелекту як однієї з базових компетентностей підготовки майбутніх фахівців різних галузей знань. Запропоновано авторське бачення постановки та актуалізачії проблеми щзодо необхідності формування емоційного інтелекту в майбутніх фахівців різного профілю як базової професійноі компетентності, яка у XXI cm. вважається однією з найбільи затребуваних на ринку праці. Розкриваються суть і змістові характеристики емоційного інтелекту й емоційної грамотності та потенційні можливості їхного використання в системі професійної освіти.

Ключові слова: емоційний інтелект; емоційна грамотність; професійна підготовка; компетентність; навички.

Jim. 13.

Borys Savchuk, Doctor of Sciences (History), Professor of the Pedagogy and Educational Technologies Department named after Bohdan Stuparyk, SHEI

"Vasyl Stefanyk Precarpathian National University"

Vera Kovalchuk, Ph.D.(Pedagogy), Professor of the Pedagogy and Educational Technologies Department named after Bohdan Stuparyk, SHEI

"Vasyl Stefanyk Precarpathian National University"

\section{FORMATION OF EMOTIONAL INTELLIGENCE AS A COMPETENCE OF A FUTURE SPECIALIST: PROBLEM STATEMENT}

We attempted to actualize the problem of forming the emotional intelligence in the educational and scientificpedagogical dimension of Ukraine as one of the basic competencies of training future specialists in various fields of knowledge. The purpose of the article is to pose and update the problem of the necessity of emotional intelligence formation among future professionals of various spheres as a basic professional competence, which is considered one of the most popular in the labor market in the XXI century. General scientific and special pedagogical methods of research are used: heuristic search, analysis and synthesis, actualization, sample analysis, content analysis, systematization of sources, etc.

As a result of the study it was found that in the global labor market, emotional intelligence is among the top 10 professional competencies most in demand in the XXI century. The scientific and theoretical developments presented in the article reveal its essence and semantic characteristics and testify to the complexity, multiplicity of manifestations of this phenomenon and give a clear idea of its main structural parameters and potential opportunities for use in vocational education to train future and advanced graduates. This fully applies to emotional literacy - a concept that is close but not identical to emotional intelligence. All this reveals the need for active internalization of these phenomena in the educational and scientific-pedagogical space of Ukraine for in-depth analysis and development of their scientific and theoretical foundations and identification and use of powerful formative (educational, developmental) potential in school education and training of competitive specialists in various fields of knowledge.

Keywords: an emotional intelligence; an emotional literacy; professional training; competence; skills.

П остановка проблеми. Всесвітній економічний форум у Давосі 2016 р. представив дані дослідження щодо визначення на основі 35 базових навичок, які визначають найбільш затребувані у XXI ст. компетентності. У процесі подальшого дослідження було опитано близько 13 млн. осіб, що працювали у 2,5 тис. кампаніях 9 провідних галузей економіки, культури, освіти, торгівлі, побуту, сфери соціального забезпечення в 13 країнах світу: Китаї, Індії, США, Бразилії, Японії, Мексики, Німеччини, Франції та ін. На цій основі були визначені ТОП-10 компетентностей, якими мають володіти фахівці у XXI ст.: 1) розв’язання 
комплексних завдань; 2) критичне мислення;

3 ) творчі навички; 4) управління людьми;

5) взаємодія з іншими; 6) емоційний інтелект;

7) осмислене (креативне) ухвалення рішень;

8) сервісна орієнтація; 9) навички ведення перемовин; 10) когнітивна гнучкість [12]. Форум у Давосі 2020 р. ствердив, що формування цих навичок має стати компасом для розвитку освітньої політики і навчання всіх країн світу [13].

Аналіз останніх досліджень. Усебічний аналіз сутності та змісту емоційного інтелекту представлено в працях зарубіжних учених Р. БарОна (R. Bar-On) [1; 11], В. Говарда (B. Govard) [5], Д. Големана (D. Goleman) [3-4], М. Мануйлової [6], Д. Ненашева, А. Петровської [8], М. Сміта (M. Smith) [9] та ін. Цей феномен активно вивчається українськими ученими-психологами (А. Книш, О. Лелюх-Степанчук, Е. Носенко та ін.). Фіксуємо продуктивні спроби обгрунтування емоційної компетенції як запоруки успішного вивчення різних дисциплін, зокрема, англійської мови (А. Чернявська [2]). Усе це актуалізує потребу більш цілісного і предметного науковотеоретичного осмислення проблеми емоційного інтелекту в українській педагогічній науці для його всебічної інтеграції упроцес професійної підготовки майбутніх фахівців у закладах вищої освіти.

Метою статті $\epsilon$ постановка й актуалізація проблеми щодо необхідності формування емоційного інтелекту в майбутніх фахівців різного профілю як базової професійної компетентності, яка у XXI ст. вважається однією з найбільш затребуваних на ринку праці.

Виклад основного матеріалу. На тлі процесів глобалізації, розвитку інформаційних технологій, швидкої появи нових галузей науки і виробництва, інших суспільних викликів у другій половині XX - на початку XXI ст. динамічно зростають вимоги до професійної підготовки майбутніх фахівців різних галузей і сфер соціального розвитку. Найбільш популярні й загальновизнані у світі сучасні моделі професійної підготовки майбутніх менеджерів та працівників високотехнологічних сфер виробництва, освіти, культури (американська, європейська, австралійська, особливо японська) грунтуються на холістському підході до формування фахівця як цілісної особистості, що має відповідати вимогам управлінця й організатора та високим психофізіологічним критеріям [7].

Високий ступінь відповідальності та психоемоційної напруги у взаєминах із суб'єктами різних галузей виробництва, соціальної сфери, зокрема й освіти, вимагає відповідної моральновольової і фізичної підготовки майбутнього фахівця. Це повною мірою стосується і формування майбутнього педагога, який зазнає значних психофізіологічних навантажень, що часто призводять до професійного вигоряння, емоційних зривів, виникнення педагогічних конфліктів, інших негативних наслідків. Вагому роль у розв'язані цих проблем, підвищенні стійкості до стресів та ефективності професійної праці загалом може відіграти формування емоційного інтелекту (Emotional Intelligence) як однієї з базових компетентностей сучасного фахівця. У концентрованому вигляді концепція емоційного інтелекту включає такі компоненти, як емоційна стриманість, урівноваженість, емпатія, уміння керувати власними емоціями, взаєминами з іншими тощо.

Зважаючи на те, що поняття “емоційний інтелект" є багатозначним й недостатньо визначеним у сучасній психології та інших суміжних галузях знань, існують різні погляди щодо його походження, тлумачення та інтерпретації. Поширена позиція, згідно з якою цей науковий термін був введений американськими психологами П. Саловеєм і Дж. Майєром у 1990 р. для позначення особливого комплексу таких психічних властивостей, як уміння розбиратися у власних почуттях, емпатія, уміння регулювати особисті емоції тощо. У студіях його послідовників Х. Вайсбаха і У. Дакса (1998) емоційний інтелект розглядається як уміння “інтелектуально" керувати своїм емоційним життям. Учені доводили, що емоційний інтелект виявляється в партнерських стосунках та розглядали його в контексті оволодіння професійним і особистим успіхом (цит. за: А. Манойлова [6, 7-8]).

Ми схиляємося до позиції, згідно з якою базові науково-теоретичні основи означеного феномена були оприлюднені в книзі Д. Големана “Емоційний Інтелект” (“Emotional Intelligence”), що з'явилася у 1995 р. Викладені в ній основи теорії емоційного інтелекту в концентрованому вигляді можна звести до низки положень. Життєвий успіх людини визначається не тільки й не стільки рівнем розумового розвитку, скільки “особливостями іiі розуму”, які визначають здатність до самопізнання й емоційної саморегуляції, уміння виражати свої почуття, розуміти та адекватно реагувати на психічний стан інших людей [3].

Саме рівень емоційного розвитку, згідно 3 думкою Д. Големана, визначає життєву і професійну успішність особи. Він послідовно обстоює позицію, що будь-яка проблема, з якою людина стикається в житті, має безліч розв'язків, тож якщо іiі аналізувати шляхом “послідовного вибору” або простого логічного аналізу, то це 

ПОСТАНОВКАПРОБЛЕМИ

унеможливлює швидке ухвалення рішень та здійснення відповідних дій. Тому людський мозок додає кожному з таких варіантів певного “емоційного навантаження", що істотно обмежує (i детермінує) сферу вибору найбільш сильних позитивних емоцій. Здійснивши при цьому помилку, людина зазвичай переживає неприємні відчуття, тому право ухвалювати оптимальне рішення пов'язується з позитивними емоціями [3; 4, 10-19].

Особливо важливу роль емоційному інтелекту Д. Големан відводив сфері міжлюдських стосунків, спілкуванню. Такі якості, як доброзичливість, тактовність, уміння швидко оцінити ситуацію і адекватно зреагувати, вимагають розвиненої емпатії. Учений вважав емпатію базовим компонентом емоційного інтелекту та визначив їі як один із чинників виживання людства, вроджену властивість людини, адже немовля проявляє це почуття в тримісячному віці, неспокійно реагуючи на плач іншої дитини [3; 4, 14-29].

На початку XXI ст. концепція емоційного інтелекту була розвинута представниками різних галузей знань - психології, філософії, освіти, менеджменту, психофізіології тощо. За таких обставин важко визначити ії цілісну концепцію, тож ми схильні розглядати емоційний інтелект як складне багаторівневе психофізіологічне явище, що помітно впливає на різні сфери суспільного життя і особистого розвитку людини.

Вагомий внесок у розвиток концепції емоційного інтелекту зробив ізраӥльськоамериканський психолог Р. Бар-Он, який у 1996 р. розробив тест EQ-i (emotional quotient- емоційний коефіцієнт), що містить перелік питань (критеріїв, ознак) з визначення коефіцієнта емоційного інтелекту. На цій основі виникла широковживана в західній науці (психології, менеджменті, соціологіï) "Модель Бар-Она" (“Bar-On model”) концепція, яку можна вважати одним з базових методологічних підходів щодо дослідження цього феномена. Вона визначає рівень сформованості EQ-i на основі оволодіння особою 15 основними здібностями (abilities): 1) самоповага усвідомлення і самооцінка своїх можливостей і обмежень, сильних і слабких якостей, сприймання себе “таким як $\epsilon$ "; 2) емоційна усвідомленість розуміння свого емоційного стану та причин його виникнення; 3) самовираження - чітке, конструктивне вираження своїх почуттів, думок, здатність мобілізувати емоційну енергію, виявляти твердість переконань; 4) незалежність - опертя на власні сили, емоційна самостійність; 5) емпатія - розпізнання, розуміння й усвідомлення почуттів іншої людини; 6) соціальна відповідальність - самоідентифікація як члена соціальної групи, конструктивна співпраця, турбота і відповідальність за себе та інших; 7) міжособистісні стосунки - встановлення взаємовигідних взаємин на основі емоційної близькості, комфортна поведінка в соціальних контактах; 8) стійкість до стресів - ефективне управління своїми емоціями, швидкий вихід зі складних ситуацій; 9) контролювання імпульсів стримування емоцій; 10) оцінка дійсності зіставлення почуттів і думок з об'єктивною реальністю; 11) гнучкість - коригування почуттів, думок, уявлень, поведінки відповідно до зміни обставин, ситуацій; 12) розв'язання проблем 3'ясування суті і пошук шляхів їхнього ефективного розв'язання; 13) самоактуалізація встановлення цілей та прагнення до їхнього досягнення на основі власного особистого потенціалу; 14) оптимізм - емоційна рівновага, позитивне ставлення і збереження надії за будьяких ситуацій; 15) щастя/благополуччя - почуття задоволення собою, іншими, життям загалом [1].

Для обгрунтування науково-теоретичних засад та всебічного аналізу концепції емоційного інтелекту доречно спиратися на його синтезоване визначення як сукупності навичок і здібностей особи розпізнавати й розуміти емоції, наміри, бажання інших людей і власні та здатність управляти ними для розв'язання практичних завдань (М. Сміт [9]).

На початку XXI ст. концепція емоційного інтелекту почала розглядатися як альтернатива традиційному інтелекту, бо, на відміну від нього, відображає єдність інтелектуальних і афективних процесів (А. Петровська [8]). Ця концепція спонукає і дає змогу правильно тлумачити ситуацію і впливати на неї; інтуїтивно вловлювати те, чого хочуть і потребують інші люди; набувати знання про сильні і слабкі риси людського характеру; ніколи не піддаватися стресу й не втрачати особисту привабливість (В. Говард [5]).

Чимало науковців уважають, що EQ (коефіцієнт емоційного інтелекту) має більшу цінність для керівників, менеджерів та спортсменів й інших осіб, зайнятих різними видами розумової і фізичної праці, аніж IQ (intelligence quotient - інтелектуальний коефіцієнт або коефіцієнт розумового розвитку). Вони доводять, що емоційний інтелект і EQ здатні справляти більший позитивний або негативний вплив (мобілізувати i дезорієнтувати, прискорювати або гальмувати тощо) на реалізацію психофізіологічного потенціалу людського організму (В. Говард [5], А. Петровська [8] та ін.). 
Поширений підхід, згідно з яким термін “емоційний інтелект” уживається як суголосний, навіть тотожний “емоційній грамотності”. Хоча вони часто використовується паралельно, іноді як взаємозамінні, між ними існують значні відмінності. Емоційну грамотність як поняття вчені почали розробляти на початку 70-х XX ст. у контексті популяризації парадигми гуманістичної освіти. Його авторство пов'язують 3 американським психологом і психотерапевтом К. Штейнером (C. Steiner). Основоположні контури своєї концепції він виклав у написаній в співавторстві з П. Перрі книзі “Досягнення емоційної грамотності” (1997), а в повному довершеному вигляді виклав іiі у праці “Емоційна грамотність; Інтелект із серцем” (2003) [10].

Емоційну грамотність К. Штейнер визначив як здатність і вміння розуміти людські емоції, почути і зрозуміти іншого, емоційно співпереживати та виразно виражати емоції. Щоб бути емоційно грамотним, за думкою вченого, варто вміти так “обробляти емоції”, щоб поліпшити особисту силу людини та якість життя навколо неї [10].

Обгрунтовуючи стрижневу ідею, згідно з якою емоційна грамотність поліпшує взаємини, створює можливість виникнення любові між людьми, уможливлює продуктивну співпрацю, стимулює почуття спільності, К. Штайнер структурував цей феномен за п'ятьма основними складниками: 1) усвідомлення почуттів; 2) володіння почуттями, співпереживання; 3 ) уміння управляти власними емоціями; 4) необхідність досягати перемоги над емоційними проблемами; 5 ) емоційна інтерактивність. Цей останній компонент інтегрує й увиразнює діяльнісний вимір емоційної грамотності як такої, що уможливлює ефективну взаємодію з іншими людьми та вироблення навичок раціональної поведінки в ситуаціях, що супроводжуються сильними емоціями [10].

Як бачимо, теоретичні концепти, що окреслюють змістову суть емоційного інтелекту та емоційної грамотності, близькі, але не тотожні за сутнісно-змістовим наповненням. Цю обставину слід ураховувати в розробці теоретичних аспектів цих феноменів та в процесі їнього використання як дієвого інструмента формування професійної компетентності майбутнього фахівця і його розвитку як цілісної особистості.

Висновки і перспективи подальших досліджень. На світовому ринку праці визнано, що емоційний інтелект входить до ТОП-10 професійних компетентностей, найбільш затребуваних у XXI ст. Представлені в статті науково-теоретичні напрацювання розкривають його суть і змістові характеристики, засвідчують складність, багаторівневість, множинність виявів цього феномена та дають достатньо чіткі уявлення про його основні структурні параметри і потенційні можливості використання у системі професійної освіти для підготовки майбутніх спеціалістів і підвищення кваліфікації дипломованих фахівців. Сказане повною мірою стосується і емоційної грамотності.

Перспективи подальших досліджень убачаємо в поглибленому всебічному вивченні феноменів емоційного інтелекту і емоційної грамотності та їхньої інтеріоризації в освітній і науковопедагогічний простір України для використання потужного формувального (навчального, виховного, розвивального) потенціалу у шкільній освіті та в підготовці конкурентоспроможних фахівців різних галузей знань.

\section{ЛІТЕРАТУРА}

1. Говард Б., Стивен С. Преимущества ЕQ. Эмоциональный интеллект и ваши успехи. Москва: Баланс Бизнес Букс, 2007. 384 с.

2. Манойлова М. А. Акмеологическое развитие эмоционального интеллекта учителей и учащихся. Псков: ПГПИ, 2004. 140 с.

3. Оу И. Японский менеджмент: прошлое, настоящее и будущее. Москва: Эксмо, 2007. 158 с.

4. Петровская А. С. Эмоциональный интеллект как детерминанта результативных параметров и процессуальных характеристик управленческой деятельности: автореф. дис. ... канд. психол. наук: 19.00.03. Ярославль, 2007. 27 с.

5. Чернявська А. Емоційний інтелект запорука успішного навчання. Молодь $і$ ринок. 2012. №12. C. 136-139.

6. Bar-On R. The Bar-On Model of EmotionalSocial Intelligence (ESI). Consortium for Research on Emotional Intelligence in Organizations. Issues in Emotional. 2005. URL: www.eiconsortium.org.

7. Goleman D. Leadership that gets results. Har-vard business review. 2000. March-April. P. 79-90.

8. Goleman D. Working with emotional intelligence. New York: Bantam Books. 1998. 464 p.

9. Smith M. K. Howard Gardner and multiple intelligences', The encyclopedia of pedagogy and informal education. 2008. URL: https:// www.infed.org/mobi/howard- Stiven DS.

10. Steiner C. Emotional Literacy; Intelligence with a Heart. 2003. 269 p.

11. The 15 factors of the Bar-On model. URL: www.reuvenbaron.org > the-5-meta-factors-and-15sub. 
12. The Future of Jobs 2016. Report. URL: www.eduget.com.

13. World economic forum, 2020. URL: www.weforum.org.

\section{REFERENCES}

1. Govard, B. \& Ctiven, C. (2007). Preimuschestva EQ. Emotsionalnyiy intellekt i vashi uspehi [The benefits of EQ. An emotional intelligence and your successes]. 384 p. [in Russian].

2. Manoylova, M. A. (2007). Akmeologicheskoe razvitie emotsionalnogo intellekta [Acmeological development of emotional intelligence of teachers and students]. 140 p. [in Russian].

3. Ou, Y. (2007). Yaponskyi menedzhment: proshloe, nastoiashchee y budushchee [Japanese Management: Past, Present and Future]. Moscov. 158 p. [in Russian].

4. Petrovskaya, A. S. (2007). Emotsionalnyiy intellekt kak determinanta rezultativnyih parametrov i protsessualnyih harakteristik upravlencheskoy deyatelnosti [An emotional intelligence as a determinant of effective parameters and procedural characteristics of management activities]. Extended abstract of candidate's thesis. Yaroslavl. 27 p. [in Russian].

5. Cherniavska, A. (2012). Emotsiinyi intelekt zaporuka uspishnoho navchannia [An emotional intelligence is the key to successful learning]. Youth \& market, Vol. 12, pp. 136-139. [in Ukrainian].

6. Bar-On, R. (2005). The Bar-On Model of Emotional-Social Intelligence (ESI). Consortium for Research on Emotional Intelligence in Organizations. Issues in Emotional. Available at: www.eiconsortium.org. (accessed 15 Apr. 2019). [in English].

7. Goleman, D. (2000). Leadership that gets results. Har-vard business review. March - April, pp. 79-90. [in English].

8. Goleman, D. (1998). Working with emotional intelligence. New York: Bantam Books. 464 p. [in English].

9. Smith, M.K. (2008). Howard Gardner and multiple intelligences'. The encyclopedia of pedagogy and informal education. Available at: https:// www.infed.org/mobi/howard- Stiven DS). [in English].

10. Steiner, C. (2003). Emotional Literacy; Intelligence with a Heart. 269 p. [in English].

11. The 15 factors of the Bar-On model. Available at: www.reuvenbaron.org > the-5-meta-factors-and15-sub.

12. The Future of Jobs 2016. Report. Available at: reports.weforum.org > future- [in English].

13. World economic forum, 2020. Available at: www.weforum.org. (accessed 15 Apr.2019). [in English].

Стаття надійшла до редакції 24.08.2020

\section{G58080ल2058080}

"Найқраша помилқа та, яқої допусқаються у навчанні".

Тригорій Сковорода уқраїнський фбілособ, педагог

“Фля вченої й освіченої ююдини жити - значить мислити.

Iицерон давнъоримський політичний діяч, філософ та літератор

“Вміння вести розмову - ие талант".

Стендаль

франиузький письменник

“Там'ять - ие мідна дошқа, вқрита буквами, яқі час непомітно згладжує, яқщо іноді їхне поновляти різием".

Dжон Лок англійський фбілособб

"Ніколи не соромся запитати про те, чого не знаєш". 